\title{
Nursing education: a conceptual analysis of the evolutionary method of Rodgers ${ }^{a}$
}

\author{
Ensino de enfermagem: uma análise do conceito segundo o método evolucionário de Rodgers \\ Enseñanza de enfermería: un análisis del concepto según el método evolucionario de Rodgers
}

\author{
Manacés dos Santos Bezerril ${ }^{1}$ (C) \\ Flávia Barreto Tavares Chiavone ${ }^{1}$ \\ Jéssica Valeska Herculano de Lima ${ }^{1}$ \\ Allyne Fortes Vitor ${ }^{1}$ \\ Marcos Antônio Ferreira Júnior ${ }^{2}$ \\ Viviane Euzébia Pereira Santos ${ }^{1}$
}

1. Universidade Federal do Rio Grande do Norte. Natal, RN, Brasil.

2. Universidade Federal de Mato Grosso do

Sul. Campo Grande, MS, Brasil.
Corresponding author:

Manacés dos Santos Bezerril.

E-mail: manacesbezerril@hotmail.com

Submitted on 03/09/2018.

Accepted on 06/12/2018.

DOI: 10.1590/2177-9465-EAN-2018-0076

\section{Abstract}

Objective: To analyze "nursing education" using Rodgers' evolutionary conceptual analysis. Method: An analysis was performed based on Rodgers' evolutionary conceptual analysis. Data collection was performed in June 2017 using the following databases: Lilacs, SciELO, Scopus, Cinahl, Web of Science, PubMed and Cochrane with the descriptors "teaching" and "nursing". The year of publication, country of origin, concept, attributes, antecedents, consequences, surrogate terms and related concepts were evaluated in the analysis of the studies. Results: The antecedents and consequences were punctuated in determinant aspects for the construction of the concept of nursing education and characteristics inherent to the training process; surrogate terms address factors of educational follow-up; the attributes of the concept may be related to the fundamentals of the teaching-learning process and resources related to teaching strategies. Conclusion: The concept of nursing education is dynamic and seeks to train professionals so that they can offer adequate care to the patient according to the transformations and needs of different populations.

Keywords: Teaching; Nursing; Concept Analysis.

\section{RESUMO}

Objetivo: Analisar o conceito "ensino de enfermagem" na perspectiva evolucionária de Rodgers. Método: Análise de conceito baseada no modelo evolucionário de Rodgers. A coleta de dados foi realizada em junho de 2017 nas seguintes bases de dados: Lilacs, SciELO, Scopus, Cinahl, Web of Science, PubMed e Cochrane, mediante o uso dos descritores "ensino" e "enfermagem". Para análise dos estudos, avaliou-se o ano de publicação, país de origem, conceito, atributos, antecedentes, consequentes, termos substitutos e conceitos relacionados. Resultados: Os antecedentes e consequentes foram pontuados em aspectos determinantes para construção do conceito de ensino de enfermagem e características inerentes ao processo de formação; os termos substitutos abordam fatores do segmento educacional; os atributos do conceito podem ser relacionados à fundamentos do processo de ensino-aprendizagem e recursos referentes às estratégias de ensino. Conclusão: Denota-se que o conceito de ensino de enfermagem é dinâmico e busca formar profissionais capazes de oferecer uma assistência adequada ao paciente, conforme as transformações e necessidades das múltiplas populações.

Palavras-chave: Ensino; Enfermagem; Análise de Conceito.

\section{Resumen}

Objetivo: Analizar el concepto "enseñanza de enfermería" bajo la perspectiva evolucionaria de Rodgers. Método: Análisis de concepto. La recogida de dato fue realizada en junio de 2017, en las bases de datos: Lilacs, SciELO, Scopus, Cinahl, Web of Science, PubMed and Cochrane; descodificadores "enseñanza" y "enfermería". Se evaluó el año de publicación, país de origen, concepto, atributos, antecedentes, consecuentes, términos substitutos y conceptos relacionados. Resultados: Los antecedentes y consecuentes fueron puntuados en aspectos determinantes para la construcción del concepto de enseñanza de enfermería y características inherentes al proceso de formación; los términos substitutos abordan factores del seguimiento educativo; los atributos del concepto pueden ser relacionados con los fundamentos del proceso de enseñanza-aprendizaje y recursos referentes a las estrategias de enseñanza. Conclusión: El concepto de enseñanza de enfermería es dinámico y busca formar profesionales capaces de ofrecer una asistencia adecuada al paciente conforme las transformaciones y necesidades de las múltiples poblaciones.

Palabras clave: Enseñanza; Enfermería; Análisis de Concepto. 


\section{INTRODUCTION}

Education is considered a facilitating form of freedom for knowledge or even an instrument of social transformation, since it must express dynamic motivation in order to create and recreate thoughts. ${ }^{1}$ In addition, it undergoes changes due to the different social, political and economic contexts experienced by the world over time..$^{2,3}$

There is evidence that the profiles of students and teachers, teaching methods and instruments, and pedagogical approaches used have gone through global influences, since according to research ${ }^{2,4}$ there has been an increase in the active participation of students in the learning process, in the optimization of academic achievement and in the educational environment making it more attractive.

Universalization and access to technology, for example, have possibly contributed to innovative education that is increasingly more accessible and diversified resulting in selfdirected, self-regulated and collaborative learning. ${ }^{4}$

These characteristics, in turn, are essential in higher education, given the need to prepare trained and efficient professionals who are adaptable to a wide range of work environments in a predominantly capitalist, unstable, flexible and competitive field. ${ }^{1,4,5}$

Health care courses are no exception but may present the greatest challenges in education due to the rapid transitions in the epidemiological profiles of the population and the search for a better quality of life in the different population groups. ${ }^{1}$

This is added to changes in the conception of health that, in the past, due to the hegemony of the biomedical model, health or the absence of a disease, was only guided by the curative sense and focused exclusively on the individual. However, with the emergence of alternative models, it is now necessary to consider the human being as a whole and to evaluate multiple contexts within the social context. ${ }^{6}$

Among the various health courses, nursing is important because it is a professional category with an expressive supply/ demand; nursing comprises a high number of active workers, whether for assistance, research or teaching in many different spheres of activities and professional categories with different educational backgrounds. . $^{3,7}$

In addition, research shows that the curriculum of nursing courses encourage the formation of humanist and generalist professionals, who develop critical and reflexive thinking and the ability to identify and solve challenges through the particularities of each context studied and experienced by considering their components and the various social, ethical-political and cultural aspects. ${ }^{1,3,5}$

Hence, it is necessary to carry out a concept analysis of nursing education in order to understand changes in the perspective of this process after so many transformations in education regarding the requirements and proposals established by new curricular guidelines and overall health needs, and how these may have influenced the formulation of the concept.

Thus, the present study has as its guiding question: how has the concept of "nursing education" been employed in scientific productions over time? The objective was to analyze "nursing education" using Rodgers' evolutionary concept analysis.

\section{METHOD}

This concept analysis is based on the Rodgers' evolutionary model, which consists of an inductive and descriptive method of analysis that aims to delineate historical knowledge used to build a concept. $^{9}$

This method is structured on six tasks proposed by Rodgers, namely: define the concept of interest; select the realm for data collection; highlight the attributes of the concept and contextual bases (antecedents and consequences); analyze the characteristics of the concept (surrogate terms and related concepts); identify, if necessary, an example of the concept and determine the implications of the concept. ${ }^{9}$

The "CAFe" authentication protocol of the Federal University of Rio Grande do Norte was used to collect data using the CAPES Journal Platform followed by a search of the Lilacs, SciELO, Scopus, Cinahl, Web of Science, PubMed and Cochrane databases in June 2017. The descriptors 'Teaching' and 'Nursing' in both English and Portuguese were used to search the databases.

There was no delimitation regarding the year of publication since the model proposed by Rodgers considers an evolutionary temporal analysis of the concept. Original and reflective studies, theses, dissertations, reports of experience and systematic reviews related to nursing education in Portuguese, English and Spanish were included if they were open access. Opinion articles, letters to the editor, integrative and literature reviews, previous notes, and duplicate studies were excluded as were articles with only the abstract available as open access.

Regarding the selection of the studies, three analyses were carried out. The first analysis consisted in the evaluation of titles and abstracts (whether or not they were about the teaching of nursing) of the publications found in the databases; the second excluded duplicate studies from the first analysis and the third involved reading the studies in full. A flowchart of the different phases of the study is shown in Figure 1.

Figure 1. Flowchart of data collection of the study. Natal, RN - 2017.

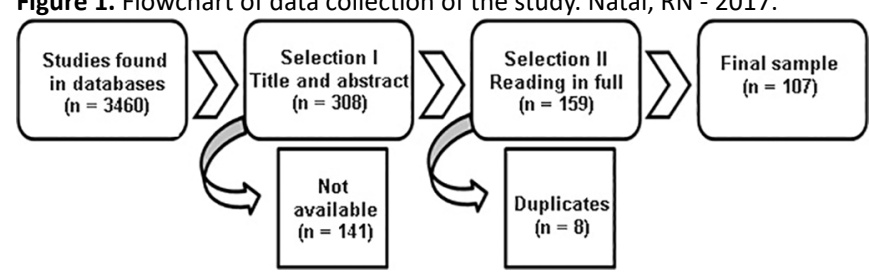


The following variables were used to analyze the studies: year of publication, country of origin, concept, attributes, antecedents, consequences, surrogate terms and related concepts. Table 1 presents the characterization of each of the elements proposed by Rodgers for concept analysis.

\section{RESULTS AND DISCUSSION}

The final sample of the study consisted of 107 articles, which were published in nine different countries with the highest number produced in Brazil (48 - 44.8\%), followed by the United States (29-27.1\%), Spain (10 - 9.5\%), Taiwan (5 - 4.6\%), Australia (5 - 4.6\%), Switzerland (4 - 3.7\%), Iran (2 - 1.9\%), Uganda (2 - 1.9\%) and Cuba (2 - 1.9\%).

The selected papers were published between 1985 and 2017 with a predominance between 2011 and 2017 (57 - 53.2\%), which shows that over the years there has been an increase in the number of publications on the teaching of nursing.

The other data of this research will be presented according to the categorization of the elements of the concept as proposed by Rodgers. These include antecedents and consequences, which include aspects and characteristics/phenomena involved in the construction of the concept; surrogate terms and related concepts, which express the words used that helped in the formation of the concept and the attributes that elucidate the characterizations of the concept.

\section{Antecedents and Consequences of the concept of nursing education}

Regarding the antecedents and consequences of the concept, the studies analyzed were determinant aspects in the construction of the concept of nursing education and characteristics inherent in the process of training professionals (Table 2).

From the analysis of the studies, particularities/facts that historically punctuated the nursing profession were identified as antecedents of the concept because nursing permeates the discovery and prevention of infectious diseases and the activities performed by Florence Nightingale - considered the mother of nursing - as well as the deficiency in the training of professionals, based on the scientificity and theories of the profession. ${ }^{10}$

Hence, it is understood that the antecedents of the concept of teaching nursing have been updated according to the social needs and speed of information associated with the progress of knowledge. This requires a constant renewal in teaching and methodologies that provide a critical and dynamic training in order to prepare professionals to address the needs of the population from the development of their psychomotor and cognitive skills. ${ }^{11}$

Regarding the consequences of this concept, there is a concern that nursing education should be increasingly complete and adapted, in order to train competent nurses to provide safe and quality health care through the nursing work process.

In this way, professional competence stands out, especially with regard to practical actions, since this technical reflection of the learning acquired during training differentiates nurses' body of knowledge from that of other professions, and demonstrates their active participation in the decisions of the multiprofessional team based on their scientific and intellectual background. ${ }^{11,12}$

At this moment, it should be noted that these skills need to be adequate for the labor market in order to meet the demands of society, which raises the relevance of constant adaptations and, thus, contributes to the preparation of effective, critical and reflexive professionals. ${ }^{12}$ In addition, the exponential growth of

Table 1. Characterization of the elements for concept analysis proposed by Rodgers. ${ }^{9}$ Natal, $\mathrm{RN}-2017$.

\begin{tabular}{|ll|}
\hline Analyzed elements & Items considered \\
\hline Antecedents & Aspects, situations and phenomena that contributed to the construction of the concept. \\
\hline Consequences & These refer to characteristics or phenomena generated after the construction of the concept. \\
Surrogate terms & Terms or expressions used that have the same meaning in articles. \\
Related concepts & Concepts that contribute to the constitution of the evaluated concept. \\
\hline Attributes & Terms or expressions that characterize the concept. \\
\hline
\end{tabular}

Table 2. Antecedents and consequences of the concept Nursing Education. Natal, RN - 2017.

\begin{tabular}{|c|c|}
\hline Antecedents & Consequences \\
\hline \multirow{6}{*}{$\begin{array}{c}\text { Florence Nightingale } \\
+ \\
\text { Deficit of professionals trained to } \\
\text { perform nursing activities } \\
+ \\
\text { Need to standardize and promote the } \\
\text { effectiveness of nursing as a profession }\end{array}$} & Construction of practical skills \\
\hline & Expansion of higher education \\
\hline & Training of critical, reflective and skilled professionals \\
\hline & Growth in scientific research \\
\hline & Valorization of the importance of the use of nursing diagnosis \\
\hline & Development of nursing theories \\
\hline
\end{tabular}


stricto sensu postgraduate programs over the last ten years is notable and may have contributed to the development of nursing education and its solidification as a science in the health area. ${ }^{10,12}$

\section{Surrogate terms and related concepts of the nursing education concept}

In general terms, the surrogate terms found address aspects of the educational process of nursing and are listed in two classifications: teaching in nursing and principles for nurse training. Concatenated to these categories are the related concepts identified in the selected studies, as shown in Figure 2.

Figure 2. Surrogate terms and concepts related to the concept of nursing education. Natal, RN - 2017.

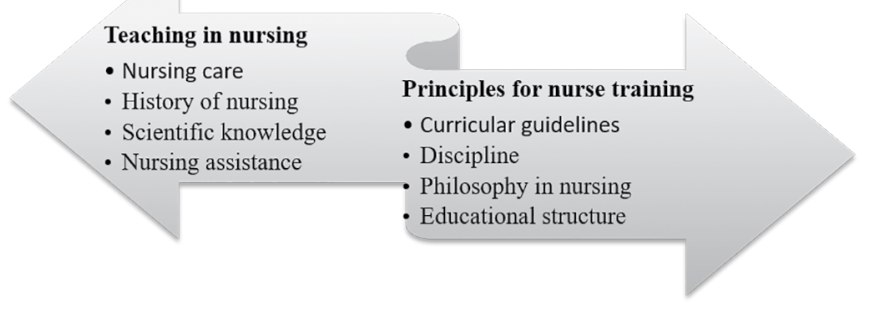

Regarding the 'teaching in nursing category', it was noticed that the related concepts mention the elements essential to nurses' education and point to the relevance of historical knowledge and the theoretical basis of nursing, such as the history of nursing and scientific knowledge that fosters their identity in science, profession and discipline. ${ }^{13}$

In addition, it is pointed out that these aspects contribute to nurse training. By themselves, however, they do not guarantee meaningful learning, and therefore require a process of teaching centered on experience, the stimulus of critical thinking, the progress of skills, and the cognitive maturation of students. ${ }^{10}$

Regarding the 'principles for nurse training', variations are assumed depending on the country including its level of development, since there are places where nursing does not have professional subcategories and has only one job description. In addition, training principles should be based on the social demands of each state. ${ }^{14}$

In addition to this difference, variations are observed in educational structures and curricular guidelines of nursing courses between countries, thereby delimiting the focus of teaching, since in most first-world institutions the practical classes and supervised internships are more common to the detriment of theoretical classes in the classroom or in laboratories; the latter are allocated considerably less time..$^{5,14}$

From this perspective, it is perceived that the importance of the development of practical activities in academic life is essential for a better use of what was acquired in theory, besides being a way to practice more and thus contribute to the students' training by providing greater insight into the meanings of what nurses do in the context of healthcare. ${ }^{5}$

To understand the concept of nursing education better, it is essential to analyze the previously discussed issues, since when linked to the rapid transitions that health field passes through over time, whether they are related to its concept or the varied epidemiological profiles experienced worldwide, it is noticed that the nursing profession has passed through similar changes.

In view of this, it is essential to reflect on this concept, due to the presence or absence of investment in education policies and changes in teaching strategies due to the transformations that occurred with time, and thus, to be able to express the idea of valuing the growth in nursing.

\section{Attributes of the concept of nursing education}

According to publications, scientific production identifies attributes of the concept because of the National Curricular Guidelines. Thus, the attributes of the concept are related to two major groups: fundamentals (in respect to the learning-teaching process) and resources (related to teaching strategies) as presented in Table 3.

Among the attributes, it is possible to note that there is a prevalence of characteristics fundamental to the education of a nurse, and that these range from practical skills and theoretical knowledge to personal qualities, such as, for example, empathy.

Therefore, nursing education is not only guided by the provision of instruction of ideas, science and techniques, but it also contributes to the training of more humanized and accessible professionals who are willing to understand the work environment and its constituents. ${ }^{6,15}$

These aspects are reflexes of the teaching-learning process, because the construction of the knowledge of each student is organized through associations of their personal experiences and the introduction of the diverse interpretations of subjects discussed by other students and their opinions. In this way what is taught approximates to what is actually learned, and thus, it stresses the attribute about the formation of competences in team activities. ${ }^{11}$

When these opportunities for systematizing cognitive ability are achieved and stimulated, critical, reflexive, creative, and technical skills are potentialized. Therefore, the probability of graduating nurses who are more capable of developing comprehensive and organized healthcare of high quality geared to the needs of the population is greater. ${ }^{10,13}$

With a view to achieving increasingly satisfactory results in nursing education, the methodological strategies used, including simulations and electronic devices, demonstrate a demand for an innovative education that is capable of making learning and teaching meaningful for teachers and for students. $2,4,11$ 
Table 3. Attributes of the concept of nursing education. Natal, RN -2017 .

\begin{tabular}{|l|}
\hline Attributes of the nurse teaching concept \\
\hline Formation of competence in team activities \\
Empathy \\
Promotion of a humanistic, critical and reflexive practices with scientific and intellectual consistency based on ethical principles \\
Professionals capable of developing comprehensive and organized care aimed at improving the quality of life of the patient \\
population \\
Valorization of theoretical and practical teaching \\
Need for the production of knowledge \\
Promotion of qualified health care
\end{tabular}

In order to do so, these new teaching tools also promote a balance between theoretical and practical teaching, facilitating comprehension of the subject taught and valuing the experiences lived in the quest for professional qualification. ${ }^{16}$

Thus, it is observed that the attributes of the concept of teaching nursing do not simply present characteristics of the concept investigated, but also provide important data to be considered and discussed in order to promote improvements in the educational process of this category of health workers.

\section{FINAL CONSIDERATIONS}

From this concept analysis, we can see that nursing education has changed over the years due to epidemiological, economic, social and cultural influences.

This demonstrates that nursing education is transformed with the purpose of meeting social demands, as well as seeking to provide for the needs of different populations. Moreover, aspects inherent to the profession started to become more important thus promoting a teaching based on science with the objective of making nursing a consolidated profession with a body of knowledge of its own.

In the meantime, it is important to remember that the concept of nursing education is dynamic and seeks to train professionals capable of offering adequate care to the patient. Thus, this concept, although current, endeavors to train generalist, humanized, critical-reflexive nurses trained to act both in individual and collective care, who are educators, managers, researchers and who have the qualifications to act in diverse contexts.

Regarding the limitations of this study, it should be pointed out that it presents a temporal delimitation, since the publications are only since 1985, and thus, do not portray concepts from earlier periods. Moreover, the articles predominantly covered university education as the means of nursing education, which, consequently, highlights the relevance of performing additional studies that investigate other academic levels.

\section{REFERENCES}

1. Noro LRA, Farias-Santos BCS, Sette-de-Souza PH, Pinheiro IAG, Borges REA, Nunes LMF, et al. O professor (ainda) no centro do processo ensino-aprendizagem em Odontologia. Rev ABENO [Internet]. 2015 Jun; [cited 2017 May 17]; 15(1):2-11. Available from: https:// revabeno.emnuvens.com.br/revabeno/article/view/146/130

2. LiYW.Transforming conventional teaching classroom to learner-centred teaching classroom using multimedia-mediated learning module. Int $\mathrm{J}$ Inform Educ Technol [Internet]. 2016 Feb; [cited 2017 May 17]; 6(2):10512. Available from: http://ijiet.org/vol6/667-K00013.pdf

3. Rodrigues CCFM, Carvalho DPSRP, Salvador PTCO, Medeiros SM, Menezes RMP, Ferreira Júnior MA, et al. Ensino inovador de enfermagem a partir da perspectiva das epistemologias do Sul. Esc Anna Nery [Internet].2016 Apr/Jun; [cited 2017 May 17];20(2):384-9. Available from: http://www.scielo.br/pdf/ean/v20n2/1414-8145-ean-20-02-0384.pdf

4. Wang VCX, Torrisi-Steele G. Online teaching, change, and critical theory. New Horiz Adult Educ Hum Resour Dev [Internet]. 2015 Apr; [cited 2017 May 17]; 27(3):18-26. Available from: http://onlinelibrary.wiley.com/ doi/10.1002/nha3.20108/epdf

5. Marran AL, Lima PG, Bagnato MHS. As políticas educacionais e o estágio curricular supervisionado no curso de graduação em enfermagem. Trab Educ Saúde [Internet]. 2015 Jan/Apr; [cited 2017 May 17]; 13(1):89-108. Available from: http://www.scielo.br/pdf/tes/ v13n1/1981-7746-tes-1981-7746-sip00025.pdf

6. Fertonani HP, Pires DEP, Biff D, Scherer MDA. Modelo assistencial em saúde: conceitos e desafios para a atenção básica brasileira. Ciênc Saúde Coletiva. [Internet].2015 Oct; [cited 2017 May 17];20(6):1869-78. Available from: http://www.scielo.br/pdf/csc/v20n6/1413-8123-csc-20-06-1869.pdf

7. Ferrel B, Malloy P, Mazanec P, Virani R. Cares: AACN's New competencies and recommendations for educating undergraduate nursing students to improve palliative care. J Prof Nurs [Internet]. 2016 Sep/Oct; [cited 2017 May 17]; 32(5):327-33. Available from: http://www. professionalnursing.org/article/S8755-7223(16)30085-0/pdf

8. Baldwin A, Bentley K, Langtree T, Mills J. Achieving graduate outcomes in undergraduate nursing education: following the Yellow Brick Road. Nurse Educ Pract [Internet]. 2014 Jun; [cited 2017 May 17]; 14(1):911. Available from: https://www.sciencedirect.com/science/article/pii/ S1471595313001303?via\%3Dihub

9. Rodgers BL. Concept Analysis: An Evolutionary View. In: Rodgers BL, Knafl KA, eds. Concept Development in Nursing - Foundations, Techniques, and Applications. 2nd ed. Philadelphia: Saunders; 2000.

10. Carbogim FC, Friedrich DBC, Puschel VAA, Oliveira LB, Nascimento HR. Paradigma da integralidade no currículo e nas estratégias de ensino em Enfermagem: um enfoque histórico-cultural. Rev Enferm Cent O Min [Internet]. 2014 Jan/Apr; [cited 2017 May 23]; 4(1):961-70. Available from: http://www.seer.ufsj.edu.br/index.php/recom/article/view/426 
11. Oliveira SN, Prado ML, Kempfer SS. Utilização da simulação no ensino da enfermagem: revisão integrativa. Rev Min Enferm [Internet]. 2014 Apr/Jun; [cited 2017 May 23]18(2):487-95. Available from: http://www. reme.org.br/artigo/detalhes/941

12. Vieira SL, Silva GTR, Fernandes JD, Silva ACAB, Santana MS, Santos TBS. De-sinteresse no ensino profissionalizante na produção do Seminário Nacional de Diretrizes para a Educação em Enfermagem. Rev Bras Enferm [Internet]. 2014 Jan/Feb; [cited 2017 May 23]; 67(1):141-8. Available from: http://www.scielo.br/pdf/reben/v67n1/0034-7167-reben-67-01-0141.pdf

13. Brehmer LCF, Ramos FRS. Experiências de integração ensino-serviço no processo de formação profissional em saúde: revisão integrativa. Rev Eletr Enferm [Internet]. 2014 Jan/Mar; [cited 2017 May 23]; 16(1):228-37. Available from: https://www.fen.ufg.br/fen_revista/v16/ n1/pdf/v16n1a26.pdf
14. Guskuma EM, Dullius AAS, Godinho MLSC, Costa MST, Terra FS Mobilidade acadêmica internacional na formação em enfermagem: relato de experiência. Rev Bras Enferm [Internet]. 2016 Sep/Oct; [cited 2017 May 23]; 69(5):929-33. Available from: http://www.scielo.br/pdf/ reben/v69n5/0034-7167-reben-69-05-0986.pdf

15. Freitas JS, Silva AEBC, Minamisava R, Bezerra ALQ, Sousa MRG Qualidade dos cuidados de enfermagem e satisfação do paciente atendido em um hospital de ensino. Rev Latino Am Enferm [Internet]. 2014 May/Jun; [cited 2017 May 23]; 22(3):454-60. Available from: http:// www.scielo.br/pdf/rlae/v22n3/pt_0104-1169-rlae-22-03-00454.pdf

16. Njie-Carr VPS, Ludeman EMSL, Lee MC, Dordunoo D, Trocky NM, Jenkins LS. An Integrative Review of Flipped Classroom Teaching Models in Nursing Education. J Prof Nurs [Internet]. 2014 Mar; [cited 2017 May 23]; 33(2):133-44. Available from: https://www.sciencedirect. com/science/article/pii/S8755722316300849?via\%3Dihub

a This article relates to a concept analysis proposed as a final activity of the course discipline 'Theoretical Knowledge of Nursing' in the Nursing Master's degree program of the Federal University of Rio Grande do Norte (UFRN). 